9. Masanobu I., Koichi K., Koji S. [et al.] Impact of aspirin on the prognosis in patients with coronary spasmwithout significant atherosclerotic stenosis. IJC. 2016;220:328332. doi: 10.1016/j.ijcard.2016.06.157

10. Ohba K., Seigo S., Hitoshi S. [et al.] Microvascular Coronary Artery Spasm Presents Distinctive Clinical Features With Endothelial Dysfunction as Nonobstructive Coronary Artery Disease. J. Am. Heart. Assoc. 2012;1:e002485. doi: 10.1161/JAHA.112.002485

11. Okazaki S., Yokoyama T., Miyauchi K. [et al.] Early statin treatment in patients with acute coronary syndrome: demonstration of the beneficial effect on atherosclerotic lesions by serial volumetric intravascular ultrasound analysis during half a year after coronary event: the ESTABLISH Study. Circulation. 2004;110(9):1061-1068. doi: 10.1161/01.CIR.0000140261.58966.A4

12. Ouldzein H., Elbaz M., Roncalli J. [et al.] Plaque rupture and morphological characteristics of the culprit lesion in acute coronary syndromes without significant angiographic lesion: analysis by intravascular ultrasound. Ann. Cardiol. Angeiol. (Paris) 2012;61:2026. doi: 10.1016/j.ancard.2011.07.011

13. Raggi P., Taylor A., Fayad Z. [et al.] Atherosclerotic plaque imaging: contemporary role in preventive cardiology. Arch. Intern. Med. 2005;165:2345-2353. doi: 10.1001/ archinte. 165.20.2345

14. Reynolds H. R., Srichai M. B., Iqbal S. N. [et al.] Mechanisms of myocardial infarction in women without angiographically obstructive coronary artery disease.

\section{About authors:}

Dyatlov Nikita, MD, CMSc, Assistant of lecturer; e-mail: nick_dv@mail.ru

Lykov Yuriy, Sixth-year student; e-mail: nick_dv@mail.ru

Zhelnov Vladimir, MD, DMSc, Professor of the chair of internal medicine № 2; e-mail: nick_dv@mail.ru

Dvoretsky Leonid, MD, DMSc, Professor, Head of the chair of internal medicine № 2; e-mail: dvoretski@mail.ru
Circulation. 2011;124:1414-1425. doi: 10.1161/ CIRCULATIONAHA.111.026542

15. Roberts James R. Angiotensin-Converting Enzyme (ACE) Inhibitor Angioedema: The Silent Epidemic. AJC. 2012 109 (5):774-775. doi: 10.1016/j.amjcard.2011.11.014

16. Taher $\mathrm{T}, \mathrm{Fu} Y$, Wagner $\mathrm{G}$. [et al.] Aborted myocardial infarction in patients with ST-segment elevation: insights from the Assessment of the Safety and Efficacy of a New Thrombolytic Regiment-3 rial Electrocardiographis Substudy. J. Am. Coll. Cardiol. 2004;44:38-43. doi: 10.1016/j.jacc.2004.03.041

17. Terkelsen C. J., Norgaard B. L., Lassen J. F. [et al.] Potential significance of spontaneous and interventional ST-changes in patients transferred for primary percutaneous coronary intervention: observations from the ST-MONitoring in Acute Myocardial Infarction study (The MONAMI study). European Heart J. 2006;27:267275. doi: 10.1093/eurheartj/ehi606

18. Thygesen K., Joseph S. Alpert, Allan S. Jaffe [et al.] Third Universal Definition of Myocardial Infarction. Circulation. 2012;126:2020-2035. doi: 10.1161/ CIR.0b013e31826e1058

19. Ueda Y., Hinoi T., Matsuo S. [et al.] Intravascular ultrasoundguided coronary artery stenting for spontaneous coronary artery dissection in a case of acute myocardial infarction associated with vasospasm in a non-culprit coronary artery during the hospitalization. Intern. Med. 2006;45:763-767. doi: 10.2169/internalmedicine.45.1688

\title{
DAYTIME SLEEPINESS AND SALIVA HORMONES FLUCTUATIONS IN MEN UNDER TOXIC STRESS
}

\author{
Budkevich R. O., Budkevich E. V., Bobrysheva T. N. \\ North-Caucasus Federal University, Stavropol, Russian Federation
}

\section{АНЕВНАЯ СОНАИВОСТЬ И КОАЕБАНИЯ ГОРМОНОВ В САЮНЕ У АИЦ МУЖСКОГО ПОАА В УСАОВИЯХ ХИМИЧЕСКОГО ЗАГРЯЗНЕНИЯ}

\author{
Р. О. БУАкевич, Е. В. БуАкевич, Т. Н. Бобрышева
}

\section{Северо-Кавказский фелеральный университет, Ставрополь, Российская ФеАерация}

The level of cortisol and testosterone in the morning and evening saliva samples and self-assessment of sleep were studied in adolescents and adults living in low and high chemical pollution regions (according the accumulation of cadmium in the hair). In the conditions of the relatively normal environment the changes in hormones level in form of its rise in the morning and decrease in the evening were noted in both age groups. In the conditions of the toxic stress the average levels of hormones increased, the morning-evening gradient disappeared. These conditions were also associated with an increase in daytime sleepiness. It was concluded that cadmium has negative impact on the sleepwake cycle and the endocrine regulation system. In particular, the changes in hormonal levels indicate the possibility of internal desynchronosis.

Keywords: cortisol, testosterone, desynchronosis, cadmium, daytime sleepiness, sleep-wakefulness cycle

Представлены результаты исследования по самооценке качества сна и определению уровней кортизола и тестостерона в слюне в утренние и вечерние часы у подростков и взрослых мужского пола, проживающих в условиях низкого и высокого химического загрязнения окружающей среды. При низком загрязнении (оценено 
по накоплению кадмия в волосах) выявлена нормальная динамика уровня гормонов с повышением их уровня в утренние часы и последующим снижением в вечерние часы. Содержание гормонов в слюне в условиях токсического стресса характеризовалось ростом их средних значений и исчезновением утренне-вечернего градиента уровней. При высоком загрязнении был выявлен повышенный уровень дневной сонливости на фоне роста нарушений гигиены сна. Сделан вывод, что при действии кадмия на организм возникают нарушения цикла «сон - бодрствование» и системы гормональной регуляции функций организма. В частности, изменения гормональных уровней указывают на возможность внутрисистемного десинхроноза.

Ключевые слова: кортизол, тестостерон, десинхроноз, кадмий, дневная сонливость, цикл «сон - бодрствование»

\section{T} he environmental condition is characterized by progressive growth of anthropogenic pollution damaging human health. Xenobiotic accumulation in the host provokes changes in homeostasis system. Our earlier investigation has shown earlier disorders of daily dynamic of visualmotor reaction and heart rate variability parameters during the daytime in teenagers and adults in the region with chemical pollution (Nevinnomyssk, Stavropol region) [5].

Based on official documents (Environmental passport of the city of Stavropol; Ecological passport of the city of Nevinnomyssk; State report «On sanitary-epidemiological situation in the Stavropol area») ecologically unfavorable situation in Nevinnomyssk is confirmed, so the region was considered as the most polluted area with high accumulation level of harmful substances.

The highly persistent and toxic heavy metal cadmium is one of the main pollutants in the region [9]. Cadmium concentration in hair of teenagers from Nevinnomyssk is 1.9 times higher than in residents from Stavropol. Cadmium accumulation is more significant in adults. Besides the described region, there are several other areas with increased technogenic loading on the south of Russia like Volgograd [8] and Vladikavkaz [17].

Cadmium is naturally found in environment in little quantities. Industrial production and consequent pollution cause local accumulation of cadmium in affected regions [4]. Cadmium is accumulated in different organs including nervous system [4, 19, 21, 24]. Cadmium has the high ability to cumulate. Even ingestion of low doses of cadmium causes oxidative and toxic stress [18]. Hair of autistic children contain a higher concentration of heavy metals (cadmium included), compared to their healthy peers. These changes are also associated with sleep disorders [1].

In the present study, we have investigated whether residence in polluted region might change morning and evening hormonal levels in saliva and specificity of sleep self-assessment of male teenagers and adults.

Material and Methods. Our studied group included 300 health male adolescents of 13-14 years old and adults. Control and experimental groups were distinguished. The control group consisted of 67 students of secondary schools and 114 university students of Stavropol city (relatively chemically clean region). 62 students of secondary schools and 57 students permanently residing and studying in Nevinnomyssk were included into the experimental group.

Daily hormonal dynamic has been registered by cross-sectional study during daytime wakefulness in two periods from 7 to $11 \mathrm{am}$ and from 4 to $8 \mathrm{pm}$. Levels of cortisol and testosterone in the saliva were tested by ELISA method using reagent kits (DRG, Germany).

Self-assessment of sleep quality was performed using «Quality of sleep hygiene» and «Sleep quality» express questionnaires. They were developed on the base of questionnaires for the subjective assessment of sleep quality $[6,15,26]$. Level of the daytime sleepiness was estimated with Epworth Sleepiness Scale [10].

Statistical analysis was carried out using selected modules of STATISTICA 10.0. The Shapiro-Wilks, nonparametric Kruskal-Wallis test, U - Mann - Whitney tests. The interaction of hormones affecting concentration factors were assessed using the two-factor and threefactor ANOVA. The concentration of hormones specified as the median hormone concentrations (interquartile range) amounts to Me (25 \%; $75 \%$ nmol/l. Differences were considered reliable at $p<0.05$, and $p<0.025$ for multiple comparison, taking into account the Bonferroni correction.

Results and Discussion. Under conditions of the relative ecological well-being during the daytime wakefulness the average daily content of cortisol in adolescent saliva was $2.83(2.43 ; 5.5) \mathrm{nmol} / \mathrm{l}$. Regular fluctuations of the cortisol level were detected. It increased in the morning hours (Figure) to 3.96 (2.70; $9.48) \mathrm{nmol} / \mathrm{l}$, and decreased in the evening hours to $2.5(2.00 ; 3.00) \mathrm{nmol} / \mathrm{l}(\mathrm{p}<0.02)$.
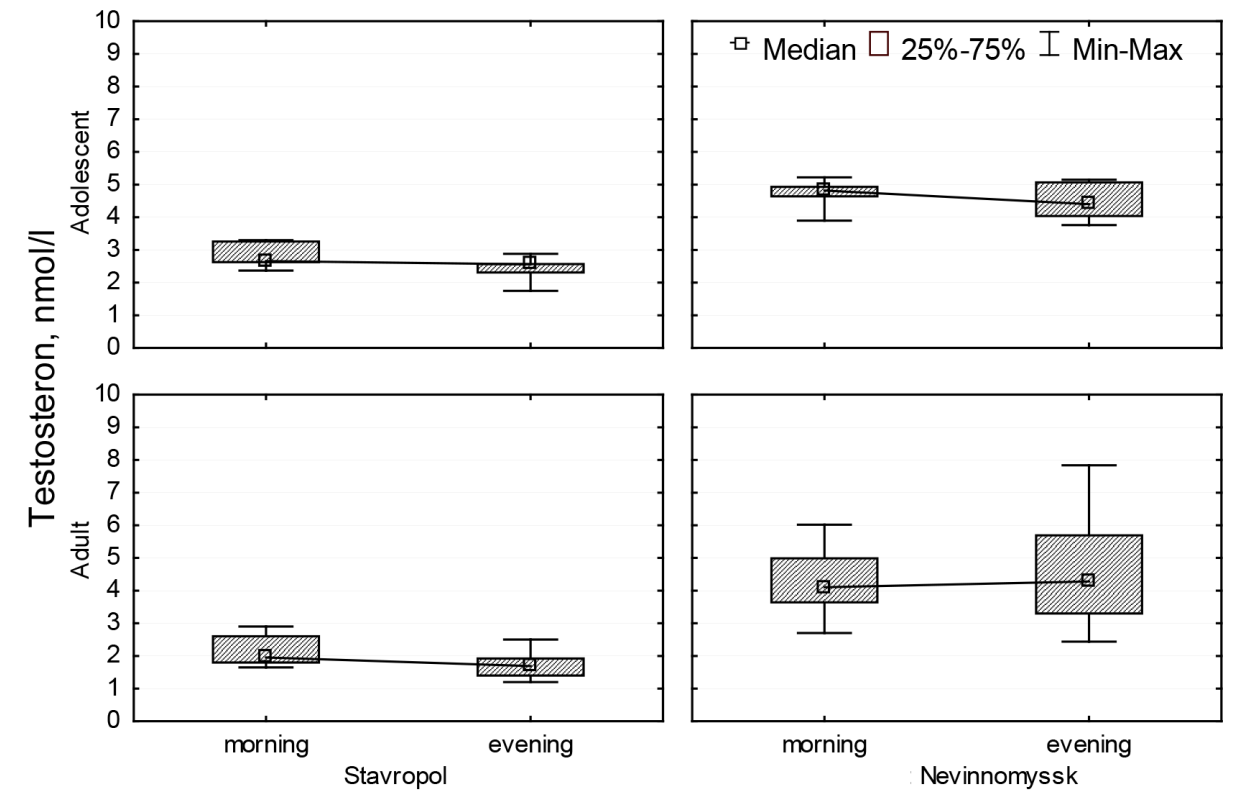

Fig. Concentration of cortisol and testosterone in saliva in the morning and evening hours in individuals living in different ecological conditions 
Similar evolution was found for testosterone concentration. Its level significantly decreased towards the evening to $2.56(2.31 ; 2.57) \mathrm{nmol} / \mathrm{l}$. The average concentration of hormone in saliva amounted to $2.58(2.37 ; 2.73) \mathrm{nmol} / \mathrm{l}$.

In the group of adult residents from Stavropol-city the average level of cortisol in saliva was 14.80 (9.07; $21.40) \mathrm{nmol} / \mathrm{I}$. In the morning hours, the hormone levels reached 21.40 (19.50; of 23.90$) \mathrm{nmol} / \mathrm{l}$. In the evening time cortisol concentration significantly decreased to $9.07(6.20 ; 13.10) \mathrm{nmol} / \mathrm{L}$. The mean values of testosterone in the saliva of adults in the control group were about 1.81 (1.65 in; 2.05) nmol/l, reliably ranging from $1.96(1.80$; of 2.60$) \mathrm{nmol} / \mathrm{l}$ in the morning, to $1.69(1.40 \mathrm{~m}$; of 1.92$) \mathrm{nmol} / \mathrm{l}$ in the evening $(\mathrm{p}<0.02)$. The pattern of testosterone changes corresponds with the previously described cortisol dynamic.

Residence in a chemically polluted area (Nevinnomyssk) was followed by a threefold increase of mean cortisol level in adolescent's saliva $(p<0.001)$ in comparison with control group. Double growth of the hormone level in the morning was detected in comparison with control data $(p<0.02)$, similar statistically significant increase was observed in the evening. The received data indicate the activation of hypothalamic-pituitary-adrenal system in teenagers consistently living in a chemically polluted area.

Cortisol level during the daytime period revealed reliable inversion of circadian changes of hormone level in saliva. So, in a chemically polluted region, the hormone concentration growth was recorded in the evening, while in the control group it was, as expected, in the morning.

In experimental group of adolescents the average concentration of testosterone reached $4.70(4.34 ; 4.98)$ $\mathrm{nmol} / \mathrm{l}$, which was significantly different to control. The concentration of testosterone in the morning was higher than one in the control group. A similar trend was observed in the evening, and the differences were statistically significant in both cases. However, there were no reliably measured differences between morning and evening saliva testosterone concentrations.

In chemically polluted area a threefold increase in mean values of cortisol in adult's saliva up to 48.93 (46.95; 51.38) nmol/l $(\mathrm{p}<0.001)$ was observed. Statistically significant fluctuations of hormone morningevening changes were not determined. The average concentration of testosterone was characterized by two-fold excess up to $4.16(3.64 ; 4.99) \mathrm{nmol} / \mathrm{l}$ in comparison with control group of adult people. Despite the lack of significant differences of average testosterone concentration rhythmical pattern, the tendency to the increase in the concentration of hormone in the evening hours was observed.

In general, the level of cortisol in saliva is higher in ecologically unfavorable region both in adolescents and in adults. It is an indicator of the increasing activity of the hypothalamic-pituitary-adrenal system. In contrast to the control, the rise of hormone levels in adolescents from Nevinnomyssk was registered in the evening, not the morning. In adults, the change in saliva cortisol concentration over the day was not detected. In sum, a violation of morning-evenings fluctuations of the hormone during daytime wakefulness was found, which indicates a failure in the circadian rhythm of cortisol in saliva. An increase in the level of testosterone in the saliva compared to the control and a differences' reducing between the morning and evening hours was marked, as well.

The results of analysis of variance showed significant influence of the studied factors on the level of cortisol and testosterone (Table 1). Three-factor analysis ANOVA revealed as a separate (main effect), and the combined effect of the factors «age», «time», "city of residence» (interaction factors). The effects differ in different severity for concentrations of cortisol in saliva. The level of testosterone is influenced only by the factors of age (weak effect) and residence (pronounced effect), but the interaction of these factors was not significant.

Table 1

Main effects and interactions of the factors "age", "time of day" and "city of residence" on the concentration of cortisol and testosterone in saliva

\begin{tabular}{|c|c|c|c|c|c|c|c|c|}
\hline \multirow{2}{*}{ Factors } & \multicolumn{4}{|c|}{ Cortisol } & \multicolumn{4}{|c|}{ Testosterone } \\
\hline & Df & $\mathrm{F}$ & $\mathrm{p}$ & $\eta 2 p$ & Df & $\mathrm{F}$ & $\mathrm{p}$ & $\eta 2 p$ \\
\hline «age» & $1 / 108$ & 1496.8 & $<0.001 *$ & 0.933 & $1 / 108$ & 11,3 & $0.001 *$ & 0.09 \\
\hline «time of day» & $1 / 108$ & 35.6 & $<0.001^{*}$ & 0.248 & $1 / 108$ & 2,3 & 0.132 & 0.021 \\
\hline «city of residence» & $1 / 108$ & 837.0 & $<0.001^{*}$ & 0.886 & $1 / 108$ & 240.6 & $<0.001 *$ & 0.690 \\
\hline «age»/«time of day» & $1 / 108$ & 12.6 & $<0.001^{*}$ & 0.104 & $1 / 108$ & 0.8 & 0.384 & 0.007 \\
\hline $\begin{array}{l}\text { «age»/《city } \\
\text { of residence» }\end{array}$ & $1 / 108$ & 470.0 & $<0.001 *$ & 0,813 & $1 / 108$ & 1.9 & 0.167 & 0.018 \\
\hline $\begin{array}{l}\text { «time of day»/《city } \\
\text { of residence» }\end{array}$ & $1 / 108$ & 19.4 & $<0.001 *$ & 0.153 & $1 / 108$ & 2.6 & 0.111 & 0.023 \\
\hline $\begin{array}{l}\text { 《age»/《time of day»/ } \\
\text { «city of residence» }\end{array}$ & $1 / 108$ & 7.2 & $0.008^{*}$ & 0.063 & $1 / 108$ & 1.1 & 0.288 & 0.010 \\
\hline \multicolumn{9}{|c|}{ Stavropol } \\
\hline «time of day» & $1 / 54$ & 38.1 & $<0.001^{*}$ & 0.414 & $1 / 54$ & 18.7 & $<0.001^{*}$ & 0.258 \\
\hline «age» & $1 / 54$ & 102.4 & $<0.001 *$ & 0.655 & $1 / 54$ & 43.3 & $<0.001^{*}$ & 0.445 \\
\hline «age»/«time of day» & $1 / 54$ & 13.8 & $<0.001^{*}$ & 0.203 & $1 / 54$ & 0.073 & 0.787 & 0.001 \\
\hline \multicolumn{9}{|c|}{ Nevinnomyssk } \\
\hline «time of day» & $1 / 54$ & 2.1 & 0.156 & 0.037 & $1 / 54$ & $<0.1$ & 0.961 & 0.001 \\
\hline «age» & $1 / 54$ & 3105.4 & $<0.001^{*}$ & 0.983 & $1 / 54$ & 1.1 & 0.296 & 0.020 \\
\hline «age»/«time of day» & $1 / 54$ & 0.6 & 0.434 & 0.012 & $1 / 54$ & 1.1 & 0.303 & 0.019 \\
\hline
\end{tabular}

The table presents the figures: Df - number of degrees of freedom; F - Fisher criterion; $\eta 2 p$ - Eta-squared; a measure of effect size for use in ANOVA; - * statistically significant $p$ values between factors allocated. 
Two-way analysis ANOVA for Stavropol (relatively chemically pure region) demonstrated a high degree of influence of the factors «age» and «time» to the hormones concentration in saliva, while the combined effect of these factors had a moderate severity and was significant only for cortisol. The analysis revealed only a strong influence of the factor age on the concentration of cortisol in chemically polluted areas (Nevinnomyssk); other significant effects were not found. The obtained data can serve as a statistical proof of changes in the level and diurnal rhythm of cortisol because of pollution.

According to the self-assessment of sleepwakefulness cycle in adolescents living in conditions of relative ecological well-being the average sleep quality was 17.0 points $(15 ; 18)$, sleep hygiene -2 points $(1 ; 3)$, the median degree of daytime sleepiness -6.0 points (3.0; 7.0). Data indicates that there was an acceptable sleep quality in compliance with sleep hygiene with some increase of sleepiness in the daytime (Table 2). The quality of sleep among adults in the control group an average was about 16 points (from 14 to 18 points). Many surveyed followed the sleep hygiene and its average mark was about 1 point (1 to 2). Indicators of daytime sleepiness were estimated in 5 points (from 2 to 8 points). Therefore, relatively favorable night sleep was revealed in this group.
Residence in a chemically polluted area was followed by a decline in sleep quality with increased values of the interquartile scale in adolescents. A similar situation occurs when daytime sleepiness was studied $(p=0.02)$.

Thus, in a group of adolescents living in a chemically unfavorable area, preclinical disorders of the sleepwakefulness cycle were detected in form of increasing in the number of respondents complaining on sleep disorders, according to the survey. In the group of adult male persons residing in the chemically polluted area, analysis showed some decrease in the self-assessment of sleep quality that was accompanied by a significant increase of the afternoon drowsiness and irregularity of the basic rules of sleep hygiene, manifested in the growth of scores and interquartile range.

According to obtained data, the residence in ecologically polluted region leads to the violation of the hormonal regulation with a rise of stress hormones and disorders of cortisol and testosterones daily fluctuations and increasing of the daily sleepiness level that indicates the decrease in level of wakefulness. Taking into account the high level of pollution by cadmium and other toxic substances of the studied area, the possible mechanisms can be explained in terms of ideas about different ways of exposure to this element on the body.

Descriptive statistics data of self-assessment of sleep state (in points)

Table 2

\begin{tabular}{|c|c|c|c|c|c|c|c|c|c|c|c|c|c|c|c|}
\hline & \multicolumn{7}{|c|}{ Ecologicaly fourable area } & \multicolumn{7}{|c|}{ Chemically polluted area } & \multirow{3}{*}{$P$} \\
\hline & \multirow{2}{*}{$\mathrm{n}$} & \multirow{2}{*}{ M } & \multirow{2}{*}{$\mathrm{m}$} & \multirow{2}{*}{$\mathrm{Me}$} & \multirow{2}{*}{ SD } & \multicolumn{2}{|c|}{ percentile } & \multirow{2}{*}{$\mathrm{n}$} & \multirow{2}{*}{ M } & \multirow{2}{*}{$\mathrm{m}$} & \multirow{2}{*}{$\mathrm{Me}$} & \multirow{2}{*}{ SD } & \multicolumn{2}{|c|}{ percentile } & \\
\hline & & & & & & 25 & 75 & & & & & & 25 & 75 & \\
\hline \multicolumn{16}{|c|}{ Adolescent } \\
\hline Sleep quality & 67 & 16.4 & 0.3 & 17.0 & 2.4 & 15.0 & 18.0 & 62 & 15.7 & 0.3 & 16.0 & 2.2 & 15.0 & 18.0 & 0.071 \\
\hline Sleep hygine & 67 & 2.1 & 0.1 & 2.0 & 1.1 & 1.0 & 3.0 & 62 & 2.7 & 0.2 & 2.0 & 1.5 & 2.0 & 4.0 & $0.018^{*}$ \\
\hline $\begin{array}{l}\text { Daytime } \\
\text { sleepiness }\end{array}$ & 67 & 5.3 & 0.3 & 6.0 & 2.7 & 3.0 & 7.0 & 62 & 6.7 & 0.4 & 6.0 & 3.1 & 4.0 & 9.0 & $0.023 *$ \\
\hline \multicolumn{16}{|c|}{ Adult } \\
\hline Sleep quality & 114 & 15.9 & 0.2 & 16.0 & 2.5 & 14.0 & 18.0 & 57 & 15.3 & 0.3 & 15.0 & 2.6 & 14.0 & 17.0 & 0.177 \\
\hline Sleep hygine & 114 & 1.6 & 0.1 & 1.0 & 1.2 & 1.0 & 2.0 & 57 & 2.6 & 0.3 & 2.0 & 2.3 & 1.0 & 3.0 & $<0.001 *$ \\
\hline $\begin{array}{l}\text { Daytime } \\
\text { sleepiness }\end{array}$ & 114 & 5.4 & 0.3 & 5.0 & 3.7 & 2.0 & 8.0 & 57 & 6.8 & 0.4 & 7.0 & 2.9 & 5.0 & 9.0 & $0.008 *$ \\
\hline
\end{tabular}

The table presents data parameters: $\mathrm{n}$ - the number of observations; $\mathrm{M}$ - mean; $\mathrm{m}$ - standard error of mean; Me - median; SD standard deviation; interquartile range; * - statistically significant P-value between environmentally friendly and chemically polluted areas highlighted.

Cadmium causes functional activity disorders of the hypothalamic-pituitary system in males [13, 14]. The mechanisms of the unfavorable toxic effects of cadmium were studied in more detail in animal experiments. A significant influence of the cadmium chloride introduction on the hypothalamic arcuate nucleus morphofunctional state has been shown in particular, involving inhibition of its synthetic activity [11]. The passage of cadmium through the blood-brain barrier and its effects on the balance of sleep and wakefulness has been shown in acute and chronic experiment on Wistar rats; intraperitoneal injection of cadmium chloride during 9 days were accompanied by epileptiform activity on the EEG with increasing of the audiogenic convulsions predisposition [23]. The cadmium chloride injection at 5 and 14 days of life lead to structural and functional changes of nerve fibers in the basal nucleus and the corpus callosum and the cerebral hemispheres of the brain [2]. Intraperitoneal administration of cadmium chloride causes changes in the structure of the sleepwakefulness cycle in rats. The experiments on animals found that intake of low doses of cadmium (100 ppm) with drinking water in the early stages of intoxication is accompanied by an increase in non-REM sleep against decrease in locomotor activity during wakefulness [22]. These changes in the structure of sleep have been associated with oxidative stress that, according to the authors, is the basis of violations of the sleep-wakefulness cycle [25]. If we consider the data on the important role of the hypothalamic-pituitary system in the organization of rhythms [7] and toxic action of cadmium on it [21, 22], the involvement of this system in the violations of daily fluctuations of hormones becomes apparent.

Hypothalamus is the central coordinator of the stress response. Stress changes the sleep state and reduces the quality of subsequent wakefulness. Non-specific manifestation of stress (regardless of its modality and duration) is increasing the activating systems activity. That's 
why awakenings become more frequent. It decreases the stability of sleep as of a functional state [20].

Any of these processes lead to pathophysiological effects in long-term compensatory mechanisms (biochemical, morphological) functioning and are accompanied by the development of the nervous and mental disorders. The occurrence of such states is accompanied by pathological integration in CNS [8], and may lead to violation of some links of multioscillatory system and the desynchronosis development.

Conclusions. Thus, for persons living in chemically polluted area violations of the levels and diurnal dynamics

\section{References}

1. Al-Ayadhi L. Y. Heavy metals and trace elements in hair samples of autistic children in central Saudi Arabia. Neurosciences. 2005;10(3):216-222.

2. Aristakesian E. A., Kiiashchenko L. I., Oganesian G. A. The effect of cadmium on the wakefulness-sleep cycle in rats in early postnatal ontogeny. Zh. Evol. Biokhim. Fiziol. 1996;32(4):327-332.

3. Asker S., Asker M., Yeltekin A. C. [et al.] Serum levels of trace minerals and heavy metals in severe obstructive sleep apnea patients: correlates and clinical implications. Sleep Breath. 2015;19(2):125-132. doi: 10.1007/ s11325-014-1045-2

4. Bernard A. Cadmium \& its adverse effects on human health. Indian J. Med. Res. 2008;128(4):557-564.

5. Budkevich E. V., Baturin V. A., Budkevich R. O., Tinkova $E$. L. Some parameters of nervous system during daytime wakefulness in adolescents living in the regions with different ecological conditions. Medical news of the North Caucasus. 2011:23(3):45-47.

6. Budkevich R. O., Bakumenko O. E., Evdokimov I. A., Budkevich E. V. Effects of nighttime snacking in students on their physiological parameters. Vopr. Pitan. 2014;83(3):17-24

7. Dedov I. I., Dedov V. I. Bioritmy gormonov. M.: Medicina; 1992

8. Gorlov I. F., Medintsev A. A., Pen'kova I. N. Heavy metals of dairy type bull-calf's meat and internal from suburb Volgograd-sity. Storage and processing of farm products. 2006;8:31-33

9. Gubareva L. I., Ermolenko G. V., Agarkova E. V., Ermolova L. S. Adaptation of the cardiovascular system of adolescents with microelementoses resulting from chemical pollution The bulletin of the Adyghe State University/In the field of Natural, Mathematical and Technical Sciences. 2012;4:93-105.

10. Johns M. W. Reliability and factor analysis of the Epworth sleepiness scale. Sleep. 1992:15(4):376-381.

11. Kotelnikova S. V., Kotelnikov A. V., Zaitsev V. F. The Impact of Toxic Stress on the Morphofunctional State of the Hypothalamic Arcuate Nucleus in the Conditions of the Changed Mode of Light Exposure. South Russ. Ecol. Dev. 2016;11(2):185-191. doi: 10.18470/1992-10982016-2-185-191

12. Kryzhanovskij G. N. Patologicheskie integracii v central'noj nervnoj sisteme. Mozg: teoreticheskie i klinicheskie aspekty. M.: Medicina; 2003. of cortisol and testosterone in saliva, preclinical misbalance of the sleep-wakefulness cycle, which is manifested in the propensity to daytime sleepiness were recorded. These changes can indicate early signs of the internal desynchronosis state in the hormonal system of regulation. Acquired data also suggest the possibility of express-evaluation of sleep quality as a marker of violations of daily hormones fluctuations in terms of the adverse effects of cadmium pollution. This approach may be interesting for environmental pathophysiology as a way of causes and mechanisms early detection for prevention of people morbidity in chemically polluted regions.

13. Lafuente A., Esquifino A. I. Cadmium effects on hypothalamic activity and pituitary hormone secretion in the male. Toxicol. Lett. 1999;110(3):209-218. doi: 10.1016/ S0378-4274(99)00159-9

14. Lafuente $A$. The hypothalamic-pituitary-gonadal axis is target of cadmium toxicity. An update of recent studies and potential therapeutic approaches. Food Chem. Toxicol. 2013;59:395-404. doi: 10.1016/j.fct.2013.06.024

15. Lubshina O. V., Vertkin A. L., Levin Ya. I. Sleep characteristics in obesity Cardiovascular Therapy and Prevention. 2007;6(1):73-78.

16. Mastin D. F., Bryson J., Corwyn R. Assessment of sleep hygiene using the sleep hygiene index. J. Behav. Med. 2006;29(3):223-227. doi: 10.1007/s10865-006-9047-6

17. Polovetskaya O. S., Platonov V. V., Khadartsev A. A. [et al.] The evaluation of ecological condition of different territories of Vladikavkaz city. Journal of New Medical Technologies. 2012;19(4):188-190.

18. Sharma B., Singh S., Siddiqi N. J. Biomedical implications of heavy metals induced imbalances in redox systems. Biomed. Res. Int. 2014;20(1):4. doi: $10.1155 / 2014 / 640754$

19. Skal'nyj A. V., Rudakov I. A. Biojelementy v medicine. M. "Oniks 21 vek»: Mir; 2004

20. Son i stress in Rukovodstvo po reabilitacii lic, pod vergshihsja stressornym nagruzkam. Pod red. akad. V. I. Pokrovskogo. M.: Medicina, 2004.

21. Sugita M., Tsuchiya K. Estimation of variation among individuals of biological half-time of cadmium calculated from accumulation data. Environ. Res. 1995;68(1):3137. doi: $10.1006 /$ enrs. 1995.1005

22. Unno K., Yamoto K., Takeuchi K. [et al.] Acute enhancement of non-rapid eye movement sleep in rats after drinking water contaminated with cadmium chloride. J. Appl. Toxicol. 2014;34(2). doi: 10.1002/jat.2853

23. Vataev S. I., Malgina N. A., Oganesian G. A. The effect of cadmium on the structure of the circadian cycle of waking-sleep and on the EEG in Wistar rats. Zhurnal Evolyutsionnoi Biokhimii i Fiziol. 1994;30(3):408-419.

24. Wang B., Du Y. Cadmium and its neurotoxic effects. Oxid Med. Cell. Longev. 2013. doi: 10.1155/2013/898034

25. Wilking M., Ndiaye M., Mukhtar H., Ahmad N. Circadian rhythm connections to oxidative stress: implications for human health. Antioxid. Redox. Signal. 2013;19(2):192208. doi: $10.1089 /$ ars.2012.4889

\section{About authors:}

Budkevich Roman Olegovich, CBS, Head of laboratory of Nanobiotechnology and biophysics of the Biotechnological Engineering Center; tel.: +79624452091; e-mail: budkev@mail.ru

Budkevich Elena Vladimirovna, CBS, Associate professor of Department of Technology of Nanomaterials; e-mail: budkevich.ev@yandex.ru Bobrysheva Tatyana Nikolaevna, CBS, Engineer of laboratory of Nanobiotechnology and biophysics of the Biotechnological Engineering Center; e-mail: samtn@front.ru 